\title{
A Study on Pink Discoloration of Canned Sand Pears (Pyrus pyrifolia Nakai)
}

\author{
Mu Ming Chang*,Tseng Kuo Chan* and Han Chang Yu* \\ * Department of Food Science, National Pingtung University of Science and Technology \\ No. 1, Hseuh Fu Road, Nei Pu, Pingtung, Taiwan. 91207.
}

\begin{abstract}
The pink discoloration occurring in canned sand pears is considered a sign of poor quality in this product. Factors contributing to pink discoloration were investigated. The major precursor of pink discoloration in canned sand pears existed in the insoluble solids of the sand pear. This precursor belonged to the flavonoids which became a pink color after being heated in acidic conditions. The pink compound was a cyanidin which was the only aglycone component in the canned sand pear. The addition of citric acid at $0.15 \%$ was sufficient to lower the $\mathrm{pH}$ below 4.6 . The use of syrup at the same degree Brix and the same sugar profile of the fruit flesh resulted in less pink discoloration than those with heavy syrup.
\end{abstract}

(Received Jul. 12, 1999; Accepted Jan. 24, 2000)

Occasionally, canned pears show a pink discoloration, which is considered undesirable ${ }^{3,4), 8,9)}$. LuH et al.$^{8)}$ showed that growing area and soil types were found to be related to pink discoloration. Pears from certain growing areas had low $\mathrm{pH}$, high acidity, high tannin and leucoanthocyanin content. The pink color was found in these pears after canning, especially when excessive heating and delayed cooling processes were used.

$\mathrm{WU}^{13)}$ studied the pink discoloration of canned lychees and found that the sterilization temperature and $\mathrm{pH}$ greatly affect the development of pink color. He also postulated that the pink discoloration in canned lychees might result from the hydrolysis of condensed tannin to catechin and lencoanthocyanin. This postulation has been reconfirmed by $\mathrm{WU}$ and $\mathrm{FANG}^{14)}$. Cyanidin compounds isolated from lychee flesh were identified with the pigment from synthetized leucocyanidin produced by heating in acidic solution. The pigment in the pink discoloration of lychee flesh was a cyanidin containing compound. CHAKRABORTY et al. ${ }^{2)}$ showed that pink discolora- tion in canned lychees could be prevented with a $20{ }^{\circ}$ Brix syrup containing $0.1 \sim 0.15 \%$ citric acid when boiled in water for less than 10 minutes. WU and FANG $^{14)}$ showed the pink discoloration of canned lychees could be reduced if the ${ }^{\circ} \mathrm{Brix}$ in syrup was adjusted to that of the fruit flesh.

The canned pear is a popular canned fruit in the market, and it occasionally shows a pink discoloration during storage. The objective of this study was to survey the pink discoloration in canned sands pears according to the above studies, and to investigate the role of leucoanthocyanidin and the effect of sugar and citric acid content on the pink discoloration in canned sand paers.

\section{MATERIALS AND METHODS}

\section{Sample}

Sand pears were picked at pear orchards from Central Taiwan. The fruits used for tests were cv. Ko-j-lee and Sin-sin.

\section{Extraction and identification of flavonoids}

The flavonoids which cause the pink discoloration of pear flesh were extracted according to the method of Forkmann ${ }^{5)}$. LEE and WICKER ${ }^{7)}$ with a 
slight modification. Four times of methanol containing $1 \% \mathrm{HCl}$ was added to the pear flesh, then blended with a Warling blender for 3 miniutes. The blended pear mash was put for reaction at $4^{\circ} \mathrm{C}$ for 48 hours with periodic stirring then filtered with a Whatman No.1 filter. The filtrate containing the flavonoids was heated at $100^{\circ} \mathrm{C}$ with a Soxhlet apparatus for $2 \mathrm{hrs}$ resulting in the filtrate changing to a pink color. The methanol in the pink solution was evaporated using a vacuum evaporator and the residue was extracted with pentanol. The pentanol extracted solution was scanned with a spectrophotomer. The flavonoid solution and the pink flavonoid solution from the pear flesh were filtered through $0.45 \mu \mathrm{m}$ cellulose acetate film. The filtrate was analyzed using HPLC with a Waters $\mu$-Bondapak C $10(30 \times 0.49 \mathrm{~cm})$ column. The mobile phase was a mixture of pure water, methanol and acetic acid at a ratio of $70: 20: 10(\mathrm{~V} / \mathrm{V})$.

The aglycone from the extract of pear flesh was prepared according to the methods of PRASAD and $\mathrm{JHA}^{10)}$. The methanol in the pink solution was removed by evaporation using a vacuum evaporator. Four normality of $\mathrm{HCl}$ was added to the solution and then it was heated with boiling water for $30 \mathrm{~min}$. in a vacuum state. After cooling, the solution was extracted with pentanol. The pentanol was then evaporated using a vacuum evaporator and the residue was dissolved in methanol with $0.1 \% \mathrm{HCl}$. This solution was filtered through $0.45 \mu \mathrm{m}$ cellulose acetate film. The filtrate was analyzed using HPLC under the previous conditions.

\section{Total soluble solids}

The fruit flesh was mashed with a blender and the juice obtained was filtered and analyzed. The total soluble solids were measured by refractometer (Bausch and Lomb Abbe- $3 \mathrm{~L}$ ) at $25^{\circ} \mathrm{C}$ and the results were expressed using ${ }^{\circ} \mathrm{Brix}{ }^{11}$.

\section{Sugar analysis by HPLC}

Sugar profile was analyzed by HPLC according to the method of WILSON et al. ${ }^{12)}$ with a slight modification. The solvents and reagents used were of analytical grade and the water was prepared using reverse osmosis. Acetonitrile: $\mathrm{H}_{2} \mathrm{O}=80: 20$ $(\mathrm{V} / \mathrm{V})$ was used as the mobile phase ${ }^{12)}$

\section{Titratable acidity}

The samples were titrated with $0.1 \mathrm{~N} \mathrm{NaOH}$ to $\mathrm{pH} 8.1^{11}$. The results were expressed as per cent citric acid.

\section{Preparation of canned sand pears}

The fruits were washed, drained and peeled by a peeling machine. The peeled fruits were washed and cut into slices with the knife and then dipped in $0.1 \%$ citric acid solution. Six syrups were prepared with three different levels of sugar content (i.e., 10.5, 18.0 and $25.5^{\circ}$ Brix) and three different levels of citric acid (i.e., $0.15,0.25$ and 0 . $35 \%$ ), respectively. The slices weighed $230 \mathrm{~g}$ with the same weight of syrup and $0.1 \% \mathrm{CaCl}_{2}$ were packed into a No.303 plain can. After being exhausted at $85^{\circ} \mathrm{C}$ for 10 minutes, those cans were sealed, sterilized in boiling water for 12 minutes, and cooled to $38^{\circ} \mathrm{C}^{14)}$. All of the canned sand pears from the different treatments were stored at $26 \pm$ $1^{\circ} \mathrm{C}$ for one year.

\section{Color measurement}

A colorimeter (JUKI JP $7100 \mathrm{~F}$, Tokyo, Japan) calibrated to a standard plate $(\mathrm{L}: 98.29, \mathrm{a}=+0.03$, $b=-0.36)$ was uesd for color measurement. The values recorded for each type of pear flesh were the average of 5 readings on different sites of the flesh. The "a" value was measured to represent the degree of the pink discoloration ${ }^{6}$.

\section{Statistical analysis}

Data were analyzed using a Statistical Analysis ${ }^{11)}$ program package. After an analysis of variance (ANOVA), a significant difference among means was determined by the Duncan Teat. Significance of differences was defined at $\mathrm{p}<0.05$.

\section{RESULTS AND DISCUSSION}

The characteristics of pink substance in canned pears.

The precursor of the pink substance extracted by methanol from that was colorless which became pink through heating. LUH et al. ${ }^{8)}$ extracted the flavonoids of pear flesh using $10 \mathrm{~g}$ of 
pear flesh with $1.5 \mathrm{~g}$ of $\mathrm{NaCl}, 2 \mathrm{~m} \ell$ of $6 \mathrm{~N} \mathrm{HCl}$ and 50 $\mathrm{m} \ell$ of butanol. This process produced the precursor of the pink substance. The aglycone type of cyandin was produced as a result of heating. In order to understand the pathway for converting leuco compounds into the pink

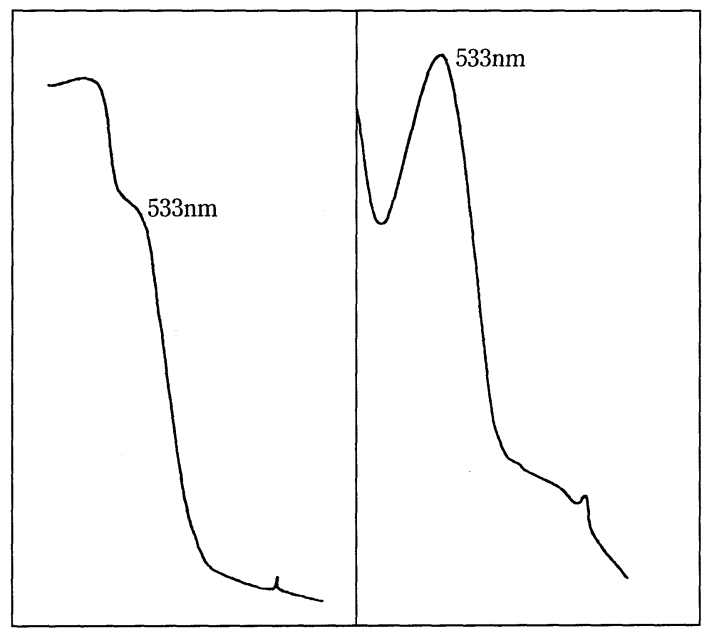

Fig. 1 The spectra of sand pear flesh extracts heated for $40 \mathrm{~min}$ (left) or $80 \mathrm{~min}$ (right)

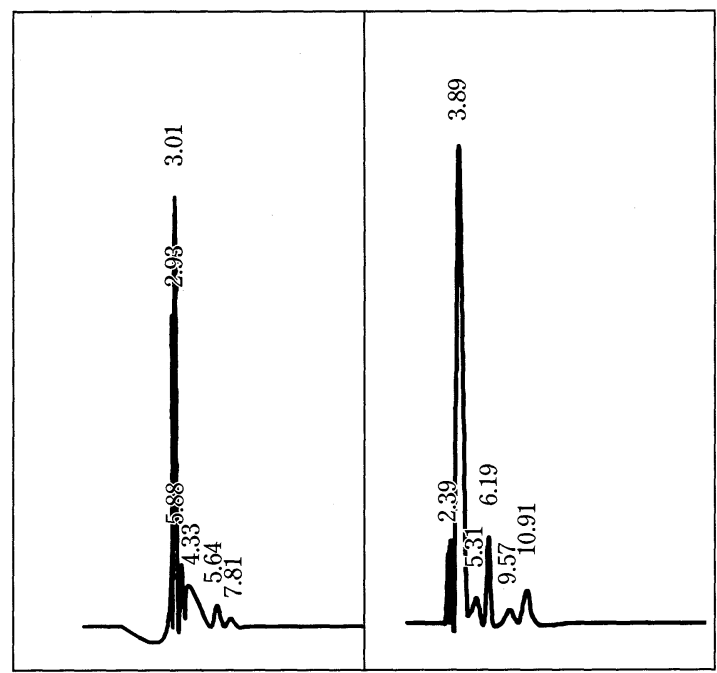

Fig. 2 High performance liquid chromatogram of sand pear flesh extract with $1 \%$ hydrochloric acid in methanol. Using $\mu$-Bondapak (Water Assoc.).

Mobile phase: methanol: acetic acid $=7: 2: 1(\mathrm{v} / \mathrm{v})$

Speed : $1 \mathrm{~m} \ell / \mathrm{min}$ and detected at $280 \mathrm{~nm}$.

Left : unheated. Right: heated. substance, it was necessary to use methanol with $1 \% \mathrm{HCl}$ as the extracting solution. This method could extract the leucocyanidin as the intermediate, and this intermediate could be regarded as the precursor of the pink substance. The effect of heating on changes of the pink substance is shown in Fig. 1. The maximum absorption of the pink extract was at $533 \mathrm{~nm}$. CHANDLER and $\mathrm{CLEGG}^{3)}$ showed the reflectance spectrum of pink pear debris had a minimum at $530-540 \mathrm{~nm}$ recorded on a Sepetrophotometer against a standard magnesium oxide block. The result from Fig.1. was similar to that of CHANDLER and $\mathrm{ClEGG}^{3}$. The longer the heating time, the higher the optical density was. From Fig. 1, it is shown that the heating time of $100 \mathrm{~min}$. would reach the maximum peak at $533 \mathrm{~nm}$ in this study, so the heating tests in this study were conducted in $100 \mathrm{~min}$.

The extract of pear flesh had the highest peak at a retention time of 2.93 and $3.01 \mathrm{~min}$ in previous analytical condition at $280 \mathrm{~nm}$ absorption as shown in Fig. 2. After the heating of the extract from pear flesh, the highest peak shifted to $3.89 \mathrm{~min}$. These result indicated that the heating caused some changes in the compounds of the extract. Some compounds became less polar due to decomposition or polymerization. The retention time of the heated compounds had a longer retention in the analysis than the unheated compounds. These results were similar to those of $\mathrm{WU}^{13)}$.

Chandler and ClegG ${ }^{13)}$ reported that the precursor of pink color contained the leucocyanidin. In this study, aglycone was produced by hydrolysis of the extract of pink compound being heated in 4 normality of $\mathrm{HCl}$. The synthetical leucocyanidin and the perilla leaf extracted by methanol with $1 \% \mathrm{HCl}$ were treated with the same procedure to produce aglycone. These three samples were analyzed using HPLC. The result indicated that the cyanidin was only aglycone in the extract of sand pear flesh (Fig. 3). This result was in agreement with the findings of LUH et al. ${ }^{8)}$ and CHANDLER and CLEGG ${ }^{13)}$. 


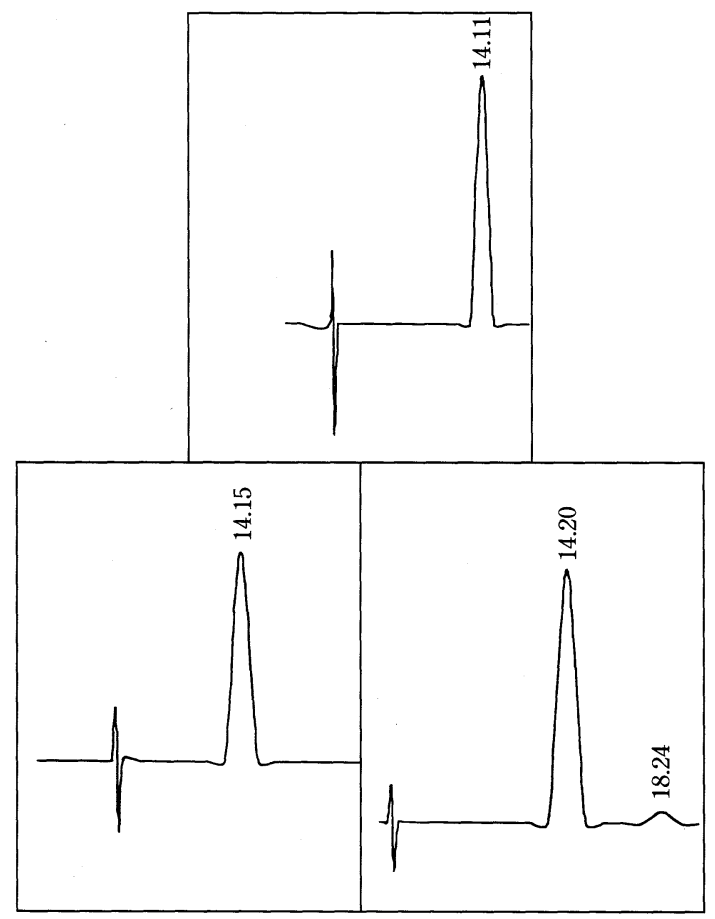

Fig. 3 High performance liquid chromatograms of cisleucocyanidin (upper) and sand pear flesh extract (left) and perilla leaf extract (right) thatwere extracted with $1 \% \mathrm{HCI}$ in methanol and after being hydrolyzed. Using $\mu$-Bondapak $\mathrm{C}_{18}$ column (Waters Assoc.) Mobile phase: Water: methanol: acetic acid= $7: 2: 1(\mathrm{v} / \mathrm{v})$, Speed : $1 \mathrm{~m} \ell / \mathrm{min}$. and detected at $533 \mathrm{~nm}$.

Table 1 Effect of citric acid and sugar on the "a" value of canned sand pears cv. Ko-j-lee storage at $26 \pm 1{ }^{\circ} \mathrm{C}$ for one year

\begin{tabular}{ccccc}
\hline $\begin{array}{l}{ }^{\circ} \text { Brix of } \\
\text { fresh flesh }\end{array}$ & $\begin{array}{l}\text { Citric acid } \\
\text { \% of pear } \\
\text { flesh }\end{array}$ & $\begin{array}{l}\text { Citric acid } \\
\% \text { added in } \\
\text { syrup }\end{array}$ & $\begin{array}{l}\text { Sugar added } \\
\text { in syrup* } \\
{ }^{\circ} \text { Brix }\end{array}$ & $\begin{array}{l}\text { "a"value } \\
\text { of canned } \\
\text { sand }\end{array}$ \\
\hline 10.5 & 0.14 & 0.15 & 10.5 & $-1.49 \mathrm{~h}$ \\
& & 0.25 & 10.5 & $-1.39 \mathrm{~g}$ \\
& & 0.35 & 10.5 & $-1.07 \mathrm{f}$ \\
& & 0.15 & 18.0 & $-1.09 \mathrm{f}$ \\
& & 0.25 & 18.0 & $-0.87 \mathrm{e}$ \\
& & 0.35 & 18.0 & $-0.49 \mathrm{~d}$ \\
& & 0.15 & 25.5 & $0.04 \mathrm{c}$ \\
& & 0.35 & 25.5 & $0.21 \mathrm{~b}$ \\
\hline
\end{tabular}

${ }^{\mathrm{a}-\mathrm{h}}$ Means with a column followed by the same subscript. letter are not significantly different $(\mathrm{p}>0.05)$ separated by the Duncan Method.

* The fraction of sugar is fructose: glucose : sucrose $=7$. $5: 2.3: 0.7$
Effect of citric acid content on the pink discoloration

Tables 1 and 2, show the "a" values for cultivars Ko-j-lee and Sin-sin. In each cultivar of sand pear, the "a" value varied with the amount of citric acid and the Brix of sugar in the syrup. The greater the amount of citric acid, the "a" value. The data in Tables 1 and 2 showed the addition of $0.15 \%$ citric acid added was sufficient to lower the $\mathrm{pH}$ below 4.6 and could prevent the pink discoloration in canned sand pears. Increasing the amounts of acids in syrup had been reported to enhance the conversion of leucoanthocyanin into anthocyanin in canned lychees, which would promote the development of a pink discoloration ${ }^{2}$.

Effect of sugar content on the pink discoloration

From Table 1 and 2, the ${ }^{\circ}$ Brix of cv. Ko-j-lee and Hsin-shui are 10.5 and 12.5 , respectively, with the same ${ }^{\circ}$ Brix of added sugar in the syrup, the tendency toward pink discoloration can be restrained. CHAKRABORTY et $a l^{2)}$ showed that there was less pink discoloration if $20^{\circ}$ Brix syrup was added to the canned lychee. The $20{ }^{\circ} \mathrm{Brix}$ of syrup is nearer the ${ }^{\circ} \mathrm{Brix}$ of lychee flesh than the $30{ }^{\circ} \mathrm{Brix}$ syrup, so the syrup containing $20{ }^{\circ} \mathrm{Brix}$ maintained better color in lychee flesh than 30

Table 2 Effect of citric acid and sugar on the"a"value of canned sand pears cv. Sin-sin storage at $26 \pm 1{ }^{\circ} \mathrm{C}$ for one year

\begin{tabular}{ccccc}
\hline $\begin{array}{l}\text { } \\
\text { Brix of } \\
\text { fresh flesh }\end{array}$ & $\begin{array}{l}\text { Citric acid } \\
\text { \% of pear } \\
\text { flesh }\end{array}$ & $\begin{array}{l}\text { Citric acid } \\
\text { \% added in } \\
\text { syrup }\end{array}$ & $\begin{array}{l}\text { Sugar added } \\
\text { in syrup* } \\
{ }^{\circ} \text { Brix }\end{array}$ & $\begin{array}{l}\text { "a"value } \\
\text { of canned } \\
\text { sand pear }\end{array}$ \\
\hline 12.5 & 0.13 & 0.15 & 12.5 & $-1.75 \mathrm{~h}$ \\
& & 0.25 & 12.5 & $-1.57 \mathrm{~g}$ \\
& & 0.35 & 12.5 & $-1.29 \mathrm{f}$ \\
& & 0.15 & 18.0 & $-1.22 \mathrm{f}$ \\
& & 0.25 & 18.0 & $-1.07 \mathrm{e}$ \\
& & 0.35 & 18.0 & $-0.69 \mathrm{~d}$ \\
& 0.15 & 23.5 & $-0.23 \mathrm{c}$ \\
& 0.25 & 23.5 & $0.06 \mathrm{~b}$ \\
& 0.35 & 23.5 & $0.16 \mathrm{a}$ \\
\hline
\end{tabular}

${ }^{\mathrm{a}-\mathrm{h}}$ Means with a column followed by the same superscript letter are not significantly different $(\mathrm{p}>0.05)$ separated by the Duncan Method.

* The fraction of sugar is fructose : glucose : sucrose $=8$. $8: 2.9: 0.8$ 
${ }^{\circ}$ Brix syrup. The results showed that the addition of $0.15 \%$ citric acid to the syrup with the ${ }^{\circ}$ Brix of sugars in the same as the sand pear flesh, the "a" value of the canned sand pear flesh was lower than those with higher Brix levels and could reduce the pink discoloration in canned sand pears (Tables 1 and 2). This could be explained in terms of the effect of osmotic pressure. If the osmotic pressure in the syrup were greater than the osmotic pressure in the flesh, more of the flesh texure would be degraded, and the pink discoloration would be increased as shown by the results of $\mathrm{WU}$ and $\mathrm{FANG}^{14)}$.

\section{CONCLUSIONS}

The major precursor of pink discoloration in canned pears existed in the soluble solids of the sand pear. This precursor belonged to the flavonoid which became a pink color after being heated in acidic conditions. The addition of $0.15 \%$ citric acid to the syrup was sufficient to lower the $\mathrm{pH}$ of the canned sand pear below 4.6. The more citric acid added, the greater the occurrence of pink discoloration was observed in the sand pear flesh. The results indicated that the use of syrup at the same ${ }^{\circ}$ Brix level and the same sugar profile of the fruit flesh could reduce the pink discoloration in canned pear products.

\section{ACKNOWLEDGMENTS}

The authors acknowledge with appreciation Prof. T. T. Fang for his supply of synthetical leucocyanidin and J. M. Lo for her technical assistance.

\section{REFERENCES}

1) AOAC.: Officaial Methods of Analysis, 15th ed. Association of Official Analytical Chemists, Washington, D C. USA. (1990)

2) Chakraborty, S. et al.: J. Food Sci. Technol, (Indi) II, 226 228 (1974)

3) Chandler, B. V. and ClegG, K. M.: J. Sci. Fd Agric., 21, 319 323 (1970)

4) CZRKaskyj, A.: J. Food Sci., 35, 608 611 (1970)
5) Forkmann, G.: Phytochemistry, 16, 299 301 (1977)

6) Hwang, L. S. and Cheng, Y. C.: Pink discoloration in canned lychee. In "Roles of Chemistry in the Quality of Processed Foods". Chapter 7, pp. 96 107. Ed. by Fannema, O. R., Chang, W. H. and Lis, C, Y, ed.. (Food and Nutrition Press, Inc., Westport, (C.T. USA.) pp. 96 107 (1986)

7) LeE, H. S. and Wicker, L.: J. Food Sci., 56, 466 $\sim 468$ (1991)

8) LuH, B. S. et al.: Food Technol., 14, 53 56 (1960)

9) Luh, B. S. and El-Tinay, A. H.: Nectars, pulpy juices and fruit juice blends. In.. "Fruit Juice Processing Technology”. NAGY, S., Chen, C. S. and SHAw, P. E. ed., (Agscience, Inc., Auburndale, Florida, USA.) pp. 560 563 (1993)

10) Prasad, U. S. and Jha, O. P.: Plant Biochem., J., 5, 44 49. (1978)

11) SAS. INSTITUTE, INC.: SAS User's Guide. Statistical Analysis System, 1989ed. (SAS Institute, Inc., Cary, NC.) (1989)

12) Wilson, C. W., Shaw, P. E. and Campbell, C. W.: J. Sci. Food Agric., 33, 777 780 (1982)

13) Wu, C. M.: J. Chiness Agric. Chem. (Spec. Iss), pp, 23 24 (1970)

14) Wu, M. C. and FAng, T. T.: J. Chinese Agri. Chem., 31, 667 672 (1993)

\section{缶詰梨 (Pyrus pyrifolia Nakai) の桃色変化 呉 明昌*, 曾 国展*, 韓 昌諭* *壂東科技大学食品学科}

\section{(テ91207 中華民國台灣省壂東県内埔郷学府路一号)}

缶詰にした梨が品質少化を起こし, 桃色となった。本 試験は桃色になった原因を探ったものである。缶詰にし た梨が桃色となった主原因は梨の中の不溶性固体物質で あることが判明した。この前駆物質はフラボイイドであ り, 酸化の環境の中で加熱すると桃色に変化した。桃色 の物質の成分はシアニジンであり，これは缶詰にした梨 のアグリコンの中の成分である。クエン酸を $0.15 \%$ に調 整し，pH を4.6に低下させ，同じ Brix と sugar の濃度 とした結果, 梨の桃色への変化は高濃度のものより減少 した。(平成11年 7 月 12 日受付, 平成 12 年 1 月 24 日受理) 